\title{
ANALISIS HARGA DAN MEKANISME PASAR DALAM PERSPEKTIF ISLAM
}

\author{
Oleh: \\ H. Idris Parakkasi dan Kamiruddin
}

Fakultas Ekonomi dan Bisnis Islam

UIN Alauddin Makassar dan IAIN Watampone

e-mail: idris_parakkasi12@yahoo.com dan kamiruddinamin@gmail.com

\begin{abstract}
ABSTRAK
Islam adalah sistem hidup yang lengkap, universal dan dinamis dalam mengatur kehidupan manusia, termasuk kaidah Islam dalam mengatur tentang harga dan mekanisme pasar. Ketentuan harga itu diserahkan kepada mekanisme pasar yang alamiah. Sistem Islam menolak menetapkan harga oleh penguasa, karena Allah-lah yang menentukannya. Harga yang terbentuk harus sesuai dengan kekuatan penawaran (suplay) dan permintaan (demand) pasar. Olehnya itu harga barang tidak boleh ditetapkan oleh pemerintah, karena ketentuan harga tergantung pada hukum supply and demand. Sistem Islam sangat mendorong harga yang adil dengan mendorong persaingan pasar yang sempurna. Untuk memenuhi harga yang adil perlu adanya moralitas (fair play), kejujuran (honesty), keterbukaan (transparancy) dan keadilan (justice) serta menghindari segala macam bentuk spekulasi. Jika nilai-nilai ini ditegakkan, maka tidak ada alasan untuk menolak harga pasar. Sistem ekonomi Islam masih memberikan peluang pada kondisi tertentu untuk melalukan intervensi harga (price intervention) oleh pemerintah bila terjadi distorsi pasar, baik yang disebabkan oleh faktor alamiah maupun perilaku menyimpang dari pelaku pasar.
\end{abstract}

Kata Kunci: Penentuan; Harga; Mekanisme Pasar. 


\section{PENDAHULUAN}

Islam adalah sistem hidup yang lengkap, universal dan dinamis. Disebut sempurna karena Islam merupakan agama penyempurna dari agamaagama sebelumnya dan syari'atnya mengatur seluruh aspek kehidupan, baik yang bersifat aqidah, syariah dan ahlak serta selalu sesuai dengan perkembangan zaman. ${ }^{1}$ Dalam kaidah tentang muamalah, Islam mengatur segala bentuk perilaku manusia dalam berhubungan dengan sesamanya untuk memenuhi kebutuhan hidupnya di dunia. Termasuk di dalamnya adalah kaidah Islam yang mengatur tentang pasar dan mekanismenya.

Dalam ekonomi kapitalis, ${ }^{2}$ pasar memainkan peranan yang sangat penting dalam sistem perekonomian. Ekonomi kapitalis menghendaki pasar bebas untuk menyelesaikan permasalahan ekonomi, mulai dari produksi, konsumsi dan distribusi. Perilaku kapitalis adalah lassez faire et laissez le monde va de lui meme (biarkan ia berbuat dan biarkan ia berjalan, dunia akan mengurus diri sendiri). Maksudnya biarkan sajalah perekonomian berjalan dengan wajar tanpa intervensi pemerintah, nanti akan ada suatu tangan tak terlihat (invisible hands) yang akan membawa perekonomian tersebut ke arah keseimbangan. Jika pemerintah campur tangan maka pasar akan mengalami distorsi yang akan membawa perekonomian pada ketidakefisienan dan ketidakseimbangan. Prinsip pasar bebas akan menghasilkan keseimbangan dalam masyarakat, di mana nantinya akan menghasilkan upah yang adil, harga barang yang stabil dan kondisi tingkat pengangguran yang rendah. Untuk itu peranan negara dalam ekonomi sama sekali harus diminimalisir, sebab kalau negara turun campur bermain dalam ekonomi hanya akan menyingkirkan sektor swasta sehingga akhirnya

\footnotetext{
${ }^{1}$ QS. Al-Maidah: 3

2 Tokoh pendiri ekonomi kapitalis adalah Adam Smith (1723-1790) dengan bukunya An Inquiry into the Nature and Causes of The Wealth of Nations, New Rochelle,, N.Y : Arlington House, 1966.
} 
mengganggu keseimbangan pasar. Maka dalam paradigma kapitalisme, mekanisme pasar bebas diyakini akan menghasilkan suatu keputusan yang adil.

Berbeda sistem ekonomi sosialis yang dikembangkan oleh Karl Max menghendaki maksimalisasi peran negara. Negara harus menguasai segala sektor ekonomi untuk memastikan keadilan kepada rakyat mulai dari produksi, konsumsi sampai mendistribusikannya kembali kepada buruh, sehingga mereka juga menikmati hasil usaha. Pasar dalam paradigma sosialis, harus dijaga agar tidak jatuh ke tangan pemilik modal yang serakah sehingga monopoli dan melakukan ekspolitasi tenaga buruh lalu memanfaatkannya untuk mendapatkan keuntungan sebesar-besarnya. Karena itu keseimbangan tidak akan pernah tercapai, sebaliknya ketidakadilan akan terjadi dalam perekonomian masyarakat. Negara harus berperan signifikan untuk mewujudkan keseimbangan, kesetaraa dan keadilan ekonomi di pasar.

Kedua ajaran sistem ekonomi di atas cukup berkembang dalam pemikiran ekonomi kontemporer, walaupun akhirnya sistem ekonomi sosialis mengalami kemunduran dan mulai ditinggalkan, sementara sistem ekonomi kapitalis banyak menimbulkan distorsi pasar, kesenjangan, keserakahan dan ketidakadilan. Islam sebagai sistem hidup dari Allah swt merupakan ajaran yang lengkap dan sempurna termasuk mekanisme pasar selalu sesuai dengan kebutuhan dan perkembangan aktivitas ekonomi manusia. Lalu bagaimana konsep ekonomi Islam tentang masalah harga, mekanisme pasar serta faktorfaktor apa yang mempengaruhi harga? 


\section{TINJAUAN TEORITIS}

\section{Grand Teori Tentang Harga}

Harga merupakan sesuatu yang diserahkan dalam pertukaran untuk mendapatkan suatu barang maupun jasa. Harga khususnya merupakan pertukaran uang bagi barang dan jasa ${ }^{3}$. Harga menurut Jerome Mc Cartgy adalah apa yang dibebabankan untuk sesuatu ${ }^{4}$. Menurut Philip Kotler harga adalah sejumlah nilai atau uang yang dibebankan atas suatu produk atau jasa untuk jumlah dari nilai yang ditukar konsumen atas manfaat-manfaat harga yang telah menjadi faktor penting yang mempengaruhi pilihan pembeli. Harga adalah satu-satunya elemen bauran pemasaran yang menghasilkan pendapatan semua elemen lainnya hanya mewakili harga. Harga adalah salah satu elemen yang paling fleksibel dari bauran pemasaran. Tidak seperti sifat-sifat produk dan komitmen jalur distribusi. Harga dapat berubah-ubah dengan cepat pada saat yang sama penetapan harga dan persaingan harga adalah masalah utama yang dihadapi banyak eksekutif pemasaran. Menurut Rachmat Syafei harga hanya terjadi pada akad, yakni sesuatu yang direlakan dalam akad baik lebih sedikit, lebih besar, atau sama dengan nilai barang. Biasanya harga dijadikan penukaran barang yang diridhai oleh kedua pihak yang melakukan akad. ${ }^{5}$ Sasaran dalam penetapan harga adalah berorientasi pada keuntungan dengan cara, Pertama, maksimalisasi keuntungan, Kedua. Keuntungan yang memuaskan, Ketiga. Target pengembalian investasi (return on investment). 6 Selain itu juga penetapan harga dengan sasaran yang berorientasi penjualan yaitu; Pertama. pangsa pasar dan kedua, maksimalisasi penjualan serta penetapan harga dengan sasaran status quo yaitu mempertahankan harga yang telah ada atau menyesuaikan diri dengan harga pesaing. Dalam struktur

${ }^{3}$ Lamb, Hair, MCDaniel. Pemasaran 2. h.268.

${ }^{4}$ Marius P. Angipora, Dasar-dasar Pemasaran, (Jakarta: PT. RajaGrafindo Persada, 2002), Cet 2, h. 26.

${ }^{5}$ Rachmat Syafei, Fiqih Muamalah, (Bandung : Pustaka Setia, 2000), h, 87.

${ }^{6}$ Lamb, Hair, MCDaniel. Pemasaran 2. h.270. 
pasar sempurna perusahaan tidak dapat menetukan harga produknya, pasarlah yang menentukan harga untuk semua produk. Produsen hanya mengambil harga yang ditetapkan oleh pasar, masing-masing produsen bertindak sebagai price taker, artinya produsen tidak mempunyai kekuatan pasar. ${ }^{7}$

\section{METODOLOGI PENELITIAN}

Metodologi yang digunakan dalam penelitian ini adalah kajian pustaka, dengan berbagai referensi yang terkait dengan tema permasalahan. Disamping itu juga membadingkan pendapat para ahli serta fenomena dan realitas perkembangan ekonomi yang ada. Termasuk data-data pendukung yang sifatnya sekunder.

\section{PEMBAHASAN}

Sistem Islam memberi perhatian terhadap kesempurnaan mekanisme pasar. Mekanisme pasar yang sempurna adalah resultan dari kekuatan yang bersifat massal dan impersonal, yaitu merupakan fenomena alamiah. ${ }^{8}$ Pasar yang bersaing sempurna dapat menghasilkan harga yang adil bagi penjual atau pembeli. Karena jika mekanisme pasar terganggu maka harga yang adil tidak akan tercapai. Harga yang adil akan mendorong para pelaku pasar untuk bersaing dengan sempurna. Sistem Islam sangat mendorong konsep harga yang adil, terbuka dan sesuai mekanisme pasar yang sempurna.

Konsep makanisme pasar dalam Islam dapat dirujuk kepada hadis Rasululllah saw sebagaimana disampaikan oleh Anas RA, sehubungan dengan adanya kenaikan harga-harga barang di kota Madinah.

Sabda Rasulullah saw yang artinya:

“Dari Anas ibn Malik ra. Berkata: Harga komoditas perdagangan beranjak naik pada zaman Rasulullah saw, lalu para sahabat mengadu kepada

\footnotetext{
${ }^{7}$ Rozalinda. Ekonomi Islam.h. 156. Raja Grafindo Persada Jakarta

${ }^{8}$ Al-ashfahani, Al-mufradat fi Gharib Al-Qur'an (Beirut: Dar at-Ma'arif tt) h.9
} 
beliau seraya berkata: Ya Rasulullah, harga barang-barang menjadi mahal, maka tetapkanlah patokan harga buat kami. Lalu Rasulullah saw menjawab: Sesungguhnya Allah lah yang menetapkan harga (Zat) Yang menahan dan yang membagikan rizki, dan sesungguhnya saya berharap agar dapat berjumpa dengan Allah SWT dalam kondisi tidak seorangpun di antara kalian yang menuntut saya karena kedzaliman yang menimbulkan pertumpahan darah dan harta."

Inilah adalah teori ekonomi Islam mengenai harga. Rasulullah saw. dalam hadis tersebut tidak menentukan harga. Ini menunjukkan bahwa ketentuan harga itu diserahkan kepada mekanisme pasar yang alamiah. Rasulullah saw. menolak tawaran itu dan mengatakan bahwa harga di pasar tidak boleh ditetapkan, karena Allah-lah yang menentukannya. Ucapan Nabi Saw itu mengandung pengertian bahwa harga pasar itu sesuai dengan kehendak Allah saw yang sunnatullah atau sesuai hukum supply and demand.

Islam menempatkan pasar pada kedudukan yang penting dalam perekonomian. Praktik ekonomi pada masa Rasulullah dan Khulafaurrasyidin menunjukkan adanya peranan pasar yang besar. Rasulullah saw sangat menghargai harga yang dibentuk oleh pasar sebagai harga yang adil. Beliau menolak adanya price intervention seandainya perubahan harga terjadi karena mekanisme pasar yang wajar. Namun pasar mengharuskan adanya moralitas (fair play), kejujuran (honesty), keterbukaan (transparancy) dan keadilan (justice). Jika nilai-nilai ini ditegakkan, maka tidak ada alasan untuk menolak harga pasar.

Para sahabat dan para imam madzhab juga memberikan pandangan dalam memahami hadis tersebut, dan realitas kebijakan Rasullullah saw. dalam menyikapi dinamika harga komoditas perdagangan, sebagai berikut:

Pertama, khalifah Umar ibn al-Khattab berpendapat bahwa dalam melindungi hak pembeli dan penjual, Islam mewajibkan pemerintah untuk melakukan intervensi harga, bila kenaikan harga disebabkan oleh distorsi penawaran dan permintaan. Umar Ibn al-Khattab pernah menegur seorang pedagang bernama Habib ibn Abi Balta'ah karena menjual anggur kering di bawah harga pasar seraya berkata: 
Artinya: Naikkan harga (daganganmu) atau engkau tinggalkan pasar kami. $^{9}$

Kedua, Imam Abu Hanifah dan Imam Malik ibn Anas membolehkan standarisasi harga komoditas tertentu dengan syarat utama bahwa standarisasi atau penetapan harga tersebut bertujuan untuk melindungi kepentingan hajat hidup mayoritas masyarakat. ${ }^{10}$ Ketiga, Imam Syafi'i dan Ahmad ibn Hanbal berpendapat bahwa pemerintah tidak memiliki hak untuk menetapkan harga dengan alasan:, Rasulullah tidak pernah menetapkan harga meskipun penduduk menginginkannya. Penetapan harga adalah ketidakadilan $(\mathrm{dzulm})$ yang dilarang, kerena persoalan ini melibatkan hak milik seseorang, sedangkan setiap orang berhak menjual komoditas perdagangannya dengan harga berapapun berdasarkan kesepakatan antara penjual dan pembeli. ${ }^{11}$

Menurut Rachmat Syafei, harga hanya terjadi pada akad, yakni sesuatu yang direlakan dalam akad, baik lebih sedikit, lebih besar, atau sama dengan nilai barang. Biasanya, harga dijadikan penukar barang yang diridai oleh kedua pihak yang akad. ${ }^{12}$

Menurut Ibnu Taimiyah yang dikutip oleh Yusuf Qardhawi: “Penentuan harga mempunyai dua bentuk yaitu ada yang boleh dan ada yang haram. Pertama, tas'ir adalah bentuk penentuan harga yang zalim, dan ini dilarang dalam syariah. Kedua harga yang adil, yaitu harga yang sesuai dengan kaidah suplay dan demand serta mekanisme pasar." Selanjutnya Qardhawi menyatakan bahwa jika penentuan harga dilakukan dengan memaksa penjual menerima harga yang tidak mereka ridhai, maka tindakan ini tidak dibenarkan oleh agama. Namun, jika penentuan harga itu menimbulkan suatu keadilan bagi

\footnotetext{
${ }^{9}$ Abdullah Alwi Hasan, Sales and Contracks in Early Islamic Comercial Law, London:

${ }^{10}$ Ibn Taimiyah, al-Hisbah fi al-Islam, Kairo: Dar al-Sya'b, 1976, h. 4

11 Ibn Taimiyah, al-Hisbah fi al-Islam, Kairo: Dar al-Sya'b, 1976, h. 37. Bandingkan dengan Ibn Qudamah al-Maqdisi, al-Syarh al-Kabir, Jilid IV, Mesir: Dar al-Syuruq, 2007, h. 44

${ }^{12}$ Rachmat Syafei, Fiqih Muamalah (Bandung : Pustaka Setia, 2000) h.8
} 
seluruh masyarakat, seperti menetapkan undang-undang untuk tidak menjual di atas harga resmi, maka hal ini diperbolehkan dan wajib diterapkan.

Menurut Qardhawi, jika pedagang menahan suatu barang, sementara pembeli membutuhkannya dengan maksud agar pembeli mau membelinya dengan harga dua kali lipat harga pertama. Dalam kasus ini, para pedagang secara suka rela harus menerima penetapan harga oleh pemerintah. Pihak yang berwenang wajib menetapkan harga itu. Dengan demikian, penetapan harga wajib dilakukan agar pedagang menjual harga yang sesuai demi tegaknya keadilan sebagaimana diminta oleh Allah. Menurut Ibnu Taimiyah "Harga ditentukan oleh kekuatan permintaan dan penawaran". "Besar kecilnya kenaikan harga bergantung pada besarnya perubahan penawaran dan atau permintaan. Bila seluruh transaksi sudah sesuai aturan, kenaikan harga yang terjadi merupakan kehendak Allah. ${ }^{13}$

Menurut Adiwarman Karim bahwa penentuan harga dilakukan oleh kekuatan-kekuatan pasar, yaitu kekuatan permintaan dan kekuatan penawaran. Dalam konsep Islam, pertemuan permintaan dengan penawaran tersebut haruslah terjadi secara rela sama rela, tidak ada pihak yang merasa terpaksa untuk melakukan transaksi pada tingkat harga tersebut. ${ }^{14}$ Jadi titik pertemuan antara permintaan dan penawaran yang membentuk harga keseimbangan hendaknya berada dalam keadaan rela sama rela dan tanpa ada paksaan dari salah satu pihak. Hal ini sesuai dengan firman Allah yang berbunyi :

Hai orang-orang yang beriman, janganlah kamu saling memakan harta sesamamu dengan jalan yang batil, kecuali dengan jalan perniagaan yang berlaku dengan suka sama suka di antara kamu. Dan janganlah kamu membunuh dirimu, sesungguhnya Allah adalah Maha Penyayang kepadamu. ${ }^{15}$

Ibnu Taimiyah menyatakan : Dalam konsep ekonomi Islam, cara pengendalian harga ditentukan oleh penyebabnya. Bila penyebabnya adalah perubahan pada genuine demand dan genuine supply, maka mekanisme pengendalian dilakukan melalui market intervention. Sedangkan bila penyebabnya adalah distorsi terhadap genuine demand dan genuine supply, maka mekanisme pengendalian dilakukan melalui

\footnotetext{
${ }^{13}$ Ibnu Taimiyah. Al-Hisbah (Cairo : Darul Sya'b, 1976) h. 24

14 Ir.Adiwarman Karim, SE, MA, op. cit., h. 236

15 QS. An-Nisaa:29
} 
penghilangan distorsi termasuk penentuan price intervention untuk mengembalikan harga pada keadaan sebelum distorsi. ${ }^{16}$

\section{Bagaimana Mekanisme Pasar Dalam Perspektif Islam}

Ekonomi Islam memandang bahwa pasar, negara, dan individu berada dalam keseimbangan (iqtishad), tidak boleh ada sub-ordinat, sehingga salah satunya menjadi dominan dari yang lain. Pasar dijamin kebebasannya dalam sistem Islam. Pasar bebas menentukan cara-cara produksi, konsumsi, distribusi dan harga selama tidak ada pelanggaran syariah. Tidak boleh ada gangguan yang mengakibatkan rusaknya keseimbangan pasar. Namun dalam kenyataannya sulit ditemukan pasar yang berjalan sendiri secara adil (fair). Distorsi pasar tetap sering terjadi, sehingga dapat merugikan berbagai pihak. ${ }^{17}$ disinilah pentingnya etika pelaku pasar dan peran pemerintah untuk membangun mekanisme pasar yang sehat, kompetitif dan adil.

Konsep makanisme pasar dalam Islam dapat dirujuk kepada hadis Rasululllah saw sebagaimana disampaikan oleh Anas ra, sehubungan dengan adanya kenaikan harga-harga barang di kota Madinah. Dalam hadis tersebut diriwayatkan sebagai berikut :

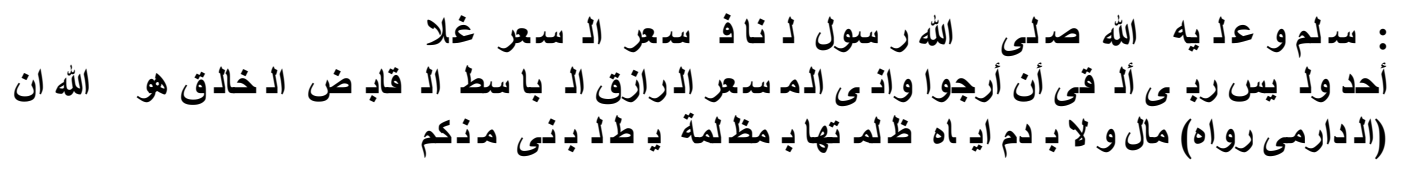

Artinya:

"Harga- harga melambung pada zaman Rasulullah saw. Orang-orang ketika itu mengajukan saran kepada Rasulullah dengan berkata: "ya Rasulullah hendaklah engkau menetukan harga". Rasulullah saw. berkata:"Sesungguhnya Allah-lah yang menetukan harga, yang menahan dan melapangkan dan memberi rezeki. Sangat aku harapkan

\footnotetext{
16 Ibnu Taimiyah, loc. cit.

17 shariaeconomics.wordpress.com/tag/mekanisme-pasar-dalam-perspektif-ekonomi-
} islam 
bahwa kelak aku menemui Allah dalam keadaan tidak seorang pun dari kamu menuntutku tentang kezaliman dalam darah maupun harta.

Jawaban Rasulullah atas kenaikan harga menunjukkan bahwa seorang penguasa atau pemerintah tidak boleh melakukan intervensi terhadap masalah harga, yang menentukan kenaikan atau penurunan harga adalah Allah yaitu terkait dengan sunnatullah dari Allah misalnya musibah, paceklik, panen raya serta keadaan ekonomi setiap individu atau masyarakat. Tingkat harga sesuai sunnatullah sesuai dengan tingkat permintaan (demand) dan penawaran (suplay). Sehingga dalam mekanisme pasar Islam semua pihak dapat menikmati harga secara adil dan secara manusiawi atau fitrah tidak terbantahkan setiap manusia.

Prinsip-Prinsip Mekanisme Pasar Dalam Islam

Konsep mekanisme pasar dalam Islam dibangun atas prinsip-prinsip sebagai berikut:

Pertama, kerelaan (Ar-ridha) yakni segala transaksi yang dilakukan haruslah atas dasar kerelaan antara masing-masing pihak (freedom contract). Hal ini sesuai dengan Qur'an Surah An- Nisa' ayat 29: “Hai orang-orang yang beriman, janganlah kamu saling memakan harta sesamamu dengan jalan yang batil, kecuali dengan jalan perniagaan yang berlaku dengan suka sama-suka di antara kamu. dan janganlah kamu membunuh dirimu; Sesungguhnya Allah adalah Maha Penyayang kepadamu."

Kedua, kejujuran (honesty), kejujuran merupakan pilar yang sangat penting dalam Islam, sebab kejujuran adalah nama lain dari kebenaran itu sendiri. Islam melarang tegas melakukan kebohongan dan penipuan dalam bentuk apapun. Sebab nilai kebenaran ini akan berdampak langsung kepada para pihak yang melakukan transaksi dalam perdagangan dan masyarakat secara luas. Ketiga, keterbukaan (transparancy). Pelaksanaan prinsip ini adalah transaksi yang dilakukan dituntut untuk berlaku benar dalam pengungkapan kehendak dan keadaan yang sesungguhnya baik hati, ucapan maupun perbuatan. Keempat, keadilan (justice), menempatkan segala mekanisme pasar sesuai proporsi, 
keadaan dan latar belakang. Kelima, Amanah, yaitu menghindari penentuan harga yang spekulatif sehingga harga yang terjadi tidak fair.

\section{Faktor-Faktor Yang Mempengaruhi Harga Dalam Islam}

Pertama, ketersediaan barang (suplay). Ketersedian barang/jasa dalam pasar akan memudahkan masyarakat untuk memenuhi kebutuhannya, sehingga harga secara relative senantiasa akan berada dalam keseimbangan. Dan sebaliknya kelangkaan akan mendorong spekluasi yang bisa berakibat pada kenaikan harga.

Menurut Ibnu Khaldun : Ketika barang-barang yang tersedia sedikit, harga-harga akan naik, Namun, bila jarak antar kota dekat dan aman untuk melakukan perjalanan, akan banyak barang yang diimpor sehingga ketersediaan barang akan melimpah, dan harga-harga akan turun. ${ }^{18}$

Kedua, rekayasa demand (ba'i Najasy) adalah produsen menyuruh pihak lain memuji produknya atau menawar dengan harga tinggi, sehingga calon pembeli yang lain tertarik untuk membeli barang dagangannya. Najasy dilarang karena dapat menaikkan harga barang-barang yang dibutuhkan oleh para pembeli.

Rasulullah saw bersabda: "Janganlah kamu sekalian melakukan penawaran terhadap barang tanpa bermaksud untuk membeli (H.R. Tirmidzi).

Ketiga, rekayasa suplay ( $b a^{\prime} i$ ikhtikar), yaitu mengambil keuntungan di atas keuntungan normal dengan cara menahan barang untuk tidak beredar di pasar supaya harga-nya naik.

Dari Ma'mar bin Abdullah bin Fadhlah, katanya, Aku mendengar Rasulullah saw bersabda, "Tidak melakukan ihtikar kecuali orang yang bersalah (berdosa)". (H.R.Tarmizi

\footnotetext{
${ }^{18}$ Ibnu Khaldun. The Muqaddimah, English Edition Transl. Franz Rosenthal (London : Rontledge \& Kegan Paul, 1967), h. 338.
} 
Keempat, Tallaqi Al-rukban, praktek ini dengan cara mencegat orangorang yang membawa barang dari desa dan membeli barang tersebut sebelum tiba di pasar. Rasulullah saw melarang praktek semacam ini dengan tujuan untuk mencegah terjadinya kenaikan harga. Beliau memerintahkan agar barang-barang langsung dibawa ke pasar, sehingga penyuplai barang dan para konsumen bisa mengambil manfaat dari harga yang sesuai dan alami.

Kelima, Terjadi keadaan Al-Hasr (pemboikotan), Yaitu distribusi barang hanya terkonsentrasi pada satu penjual atau pihak tertentu. Perlu penetapan harga di sini untuk menghindari penjualan barang tersebut dengan harga yang ditetapkan sepihak dan semena-mena oleh pihak penjual tersebut. Keenam, terjadi koalisi dan kolusi antar penjual (kartel) di mana sejumlah pedagang sepakat untuk melakukan transaksi di antara mereka, dengan harga di atas ataupun di bawah harga normal. Ketujuh, ta'sir (penetapan harga) merupakan salah satu praktek yang tidak dibolehkan oleh syariat Islam.

Rasulullah saw bersabda:

"Fluktuasi harga (turun-naik) itu adalah perbuatan Allah, sesungguhnya saya ingin berjumpa dengan-Nya, dan saya tidak melakukan kezaliman pada seorang yang bisa dituntut dari saya" $(\mathrm{HR}$. Abu Dawud). ${ }^{19}$

Kedelapan, Larangan $b a^{\prime} i$ ba'dh 'ala $b a^{\prime} d h$. Yaitu praktek bisnis ini maksudnya adalah dengan melakukan lonjakan atau penurunan harga oleh seseorang dimana kedua belah pihak yang terlibat tawar menawar masih melakukan dealing, atau baru akan menyelesaikan penetapan harga. Rasulullah saw melarang praktek semacam ini karena hanya akan menimbulkan kenaikan harga yang tak diinginkan. Rasulullah saw bersabda:

${ }^{19}$ Abu Daud, Sunan Abu Daud, No Hadits 3450, jilid III, Dar al-Hadits Syuriah,tt. 
"Janganlah sebagian dari kamu menjual atau penjualan sebagian yang lain"(HR. Tirmidzi) ${ }^{20}$

Kesembilan Larangan Maks (Pengambilan Bea cukai/pungli), yaitu pembebanan bea cukai sangatlah memberatkan dan hanya akan menimbulkan melambungnya secara tidak adil, maka Islam tidak setuju dengan cara ini. Rasulullah saw dalam hal ini bersabda, "Tidak akan masuk syurga orang yang mengambil beacukai. ${ }^{21}$

Kesepuluh, Tadlîs (Penipuan), yaitu kondisi ideal dalam pasar adalah apabila penjual dan pembeli mempunyai informasi yang sama tentang barang yang akan diperjualbelikan. Apabila salah satu pihak tidak mempunyai informasi seperti yang dimiliki oleh pihak lain (assymetric information), maka salah satu pihak akan merasa dirugikan dan terjadi kecurangan/penipuan. ${ }^{22}$

\section{PENUTUP}

\section{Kesimpulan}

Islam menempatkan pasar pada kedudukan yang penting dalam perekonomian. Praktik ekonomi pada masa Rasulullah dan Khulafaurrasyidin serta tabi' in menunjukkan adanya peranan pasar yang sangat besar. Rasulullah saw sangat menghargai harga yang dibentuk oleh mekanisme pasar sebagai harga yang adil. Beliau menolak adanya intervensi harga (price intervention) seandainya perubahan harga terjadi karena mekanisme pasar yang wajar atau alami. Namun harga yang adil dapat tercipta dipasar bila adanya moralitas (fair play), kejujuran (honesty), keterbukaan (transparancy) dan keadilan (justice). Jika nilai-nilai ini ditegakkan, maka tidak ada alasan untuk menolak harga pasar. Disamping itu pemerintah dapat melakukan intervensi harga apabila Beirut, h 37

${ }^{20}$ At-Tirmizy, Al-Jami Shahih Sunan At-Tirmizy, No Hadits 1310, Juz III, Dar al-Fikri

${ }^{21}$ Hadits ini dikutip oleh S.M.Yusuf, op.cit., h 47 dan Mustaq Ahmad, op.cit, h 148

${ }^{22}$ Adiwarman A Karim, Ekonomi Mikro Islami, h. 15 
terjadi distorsi pasar, baik secara alamiah (faktor alam) maupun perilaku pasar yang menyimpan. Olehnya itu perlu ada badan hisbah untuk memantau mekanisme harga yang terjadi di pasar sehingga tercipta mekanisme pasar yang sehat, adil, dan memiliki keberkahan.

\section{DAFTAR PUSTAKA}

Ahmad, Mustaq, Etika Bisnis dalam Islam, Terjemahan Zainal Arifin, Gema Insani Press, Cet 1, Jakrta, 1997

Adiwarman A.Karim, Ekonomi Islam Suatu Kajian Kontemporer, Gema Insani 2001

Fachruddin,"Makalah Diskusi Sejarah Pemikiran Ekonomi Islam pada masa Rasulullah SAW.

Ibnu Khaldun.1967. The Muqaddimah, English Edition Transl. Franz Rosenthal (London : Rontledge \& Kegan Paul)

Karim, Adiwarman, Ekonomi Islam Suatu Kajian Kontemporer, Jakarta : Gema Insani Press, 2003.

, Ekonomi Mikro Islam, Jakarta : III T Indonesia, 2003.

Khaldun, Ibnu, The Muqaddimah, English Edition Transl. Franz Rosenthal, London : Rontledge \& Kegon Paul, 1967.

Lamb, Hair, MCDaniel, 2001. Pemasaran 2. Penerbit Selemba Empat. Jakarta

Mannan, M.A. Ekonomi Islam Teori dan Praktek (terj.). Yogjakarta: PT. Dana Bhakti Wakaf. 1997

Mustafa Edwin.N., Dkk,2015. Pengenalan Ekslusif Ekonomi Islam. Prenadmedia Group, Jakarta

Pusat Pengkajian dan Pengembangan Ekonomi Islam (P3EI), 2009. Ekonomi Islam. Rajawali Pers. PT. Raja Grafindo Persada, Jakarta

Qardhawi, Yusuf, Norma dan Etika Ekonomi Islam, diterjemahkan oleh Zainal Arifin Lc dan Dra. Dahlia Husin, Jakarta : Gema Insani, 1997.

Rachmat Syafei, 2000. Fiqih Muamalah, (Bandung: Pustaka Setia)

Rozalinda, 2014. Ekonomi Islam. Teori dan Aplikasinya pada Aktivitas Ekonomi. Raja Grafindo Persada jakarta. 